\title{
Goussia carpelli (Protozoa: Coccidia) infection in stressed and immunosuppressed common carp Cyprinus carpio
}

\author{
Dieter Steinhagen*, Katharina Hespe, Birgitt Ellmer, Wolfgang Körting
}

Fish Disease Research Unit, School of Veterinary Medicine, Bünteweg 17, D-30559 Hannover, Germany

\begin{abstract}
Goussia carpelli causes enteritic coccidiosis in juvenile carp. In nature it affects carp fry ( 1 to 2 mo old) and fish ( 3 to 4 mo old) which are subjected to environmental stress. Carp treated with corticosteroids or subjected to temperature stress in the laboratory produced higher numbers of oocysts during the primary infection. Resistance to reinfection via the fecal contamination route, however, was not reduced by the application of hydrocortisone, dexamethasone, or X-ray irradiation given both prior to and concurrently with reinfection. The administration of hydrocortisole or irradiation did not induce a relapse of a previous infection. Carp which had been immunosuppressed by hydrocortisole injection during a primary infection were also refractory to a secondary infection via fecal contamination. The results of these experiments suggest that the mechanisms which are responsible for the resistance of carp to secondary infections with Goussia carpelli were not affected by hydrocortisole, dexamethasone or X-ray treatment.
\end{abstract}

KEY WORDS: Carp coccidiosis · Immunosuppression - Cortisol - Goussia carpelli - Cyprinus carpio

\section{INTRODUCTION}

In European carp hatcheries, fry are often infected by Goussia carpelli, which causes enteritic coccidiosis. The transmission of the parasite to uninfected carp occurs via fecal contamination and indirect transmission via tubificid oligochaetes (Steinhagen \& Körting 1990). Carp which had recovered from a $G$. carpelli infection were refractory to a secondary infection via fecal contamination (Steinhagen \& Körting 1990). In nature, the main source of infection is pond sediment, which contains both high numbers of infective oocysts and infected tubificids (Steinhagen \& Hespe 1998). In the hatchery, carp 3 to $4 \mathrm{wk}$ post-hatch harbour merogonic, gamogonic and sporogonic developmental stages of $G$. carpelli. Laboratory-infected carp start to excrete oocysts in feces at about $10 \mathrm{~d}$ post initial exposure (PE) to oocysts (Steinhagen et al. 1989). In these

•E-mail: dstein@fish.tiho-hannover.de fish a severe destruction of the absorptive intestinal epithelium was observed (Jendrysek et al. 1994), losses of serum proteins and ions occurred and the susceptibility of carp to infections with opportunistic bacteria increased (Steinhagen et al. 1997). In hatchery populations, enteric coccidiosis is considered a serious disease in carp fry 1 to 2 mo old (Kocylowski et al. 1976. Schäperclaus 1979), but it also was found to affect juvenile fish subjected to temperature stress in fall or spring (Proske 1996).

It is well established that environmental stress influences the susceptibility of fish to opportunistic pathogens (Bly et al. 1997) and triggers the outbreak of infectious diseases (Snieszko 1974, Maule et al. 1989). Many stress factors induce immunosuppression and are frequently associated with elevated glucocorticoid or adrenocorticotropic hormone (ACTH) levels (Balm \& Pottinger 1995). Laboratory studies have documented that the exogenous adminstration of cortisol to salmonids (Esplid et al. 1996), catfish (Elsaesser \& Clem 1987), and carp (Houghton \& Matthews 1990) 
mimics the suppressive effects of environmental stress factors.

To monitor the influence of some stress factors on the susceptibility of carp to Goussia carpelli, we monitored oocyst production in laboratory-infected carp which were subjected to temperature stress and treated with cortisol. Furthermore, the resistance of carp to secondary infections with $G$. carpelli was investigated by cortisol administration or $\mathrm{X}$-ray irradiation.

\section{MATERIALS AND METHODS}

Carp. Carp of a single crossing (E20xR8, Wageningen Agricultural University, The Netherlands) were used for all experiments. The fish were bred and raised in coccidia-free tanks filled with tap water at $22^{\circ} \mathrm{C}$ and fed with Artemia salina nauplii and commercial fish food (Trouvit, The Netherlands).

Infection with Goussia carpelli. The fish were exposed and became infected with $G$. carpelli as described previously (Steinhagen \& Körting 1990). Briefly, the fish were placed into tanks containing $10^{5}$ G. carpelli oocysts for at least $24 \mathrm{~h}$ and then transferred to clean tanks with tap water at $20^{\circ} \mathrm{C}$. For controls, uninfected carp from the same stock were kept under identical conditions.

Applications of immunosuppressants. Hydrocortisole (hydrocortisone-21-hemisuccinate, Sigma, St. Louis, USA) was suspended in phosphate buffered saline (PBS, $\mathrm{pH} 7.2$ ) and injected into the peritoneal cavity of carp every 4 d during a $30 \mathrm{~d}$ period at a dosage of $200 \mathrm{ug} \mathrm{g}^{-1}$ body weight (Houghton \& Matthews 1990). Dexamethasone-21-isonicotinate (Voren ${ }^{\mathrm{M}}$, Boehringer Ingelheim, Germany) suspended with PBS was injected into the peritoneal cavity at a dosage of $2.5 \mu \mathrm{g} \mathrm{g}^{-1}$ body weight. The first injection of the steroids was given $4 \mathrm{~d}$ prior to the exposure to the parasite.

In irradiation experiments, carp were exposed to X-rays at a dosage between 10 and 12 Gray. During irradiation the carp were kept in a 21 plastic container surrounded with $5 \mathrm{~cm}$ backscattering material.

Collection and counting of oocysts. Excreted oocysts were collected from each fish individually. Beginning with Day 7 PE, carp were placed individually into $2 \mathrm{l}$ plastic containers with tap water at $20^{\circ} \mathrm{C}$. From these containers, the water was collected in a funnel every other day, a drop of detergent added and the oocysts allowed to settle overnight. The next day, $50 \mathrm{ml}$ of water with the sediment was drawn into centrifuge tubes and spun at $550 \times g$ for $10 \mathrm{~min}$ at $20^{\circ} \mathrm{C}$. The sediment was collected, resuspended in ca 2 to $3 \mathrm{ml}$ water and then transferred into a $5 \mathrm{ml}$ plankton chamber mounted onto an inverted microscope (Zeiss, Germany). The preparations were observed with a $40 \times$ objective and the oocysts were counted in 50 fields of view (ca $12 \mathrm{~mm}^{2}$ ).

Determination of infection status. To determine the infection status of carp, the fish were killed by immersion into 0.05\% tricaine (Sigma, St. Louis, USA), necropsied and scrapings of the intestinal mucosa were taken from 3 different locations in the gut. The scrapings were air dried, Giemsa stained (Romeis 1968) and observed for Goussia carpelli sprorogonic stages in a light microscope. Infection intensities were estimated on a qualitative scale: not infected $(-)$, low infection $(+)$, medium infection $(++)$, and high infection $(+++)$.

Oocyst production in stressed and immunosuppressed carp. To examine the effect of an external stress factor on the oocyst production, carp were subjected to alternating water temperatures during a Goussia carpelli infection. For the experiment 10 carp (9 mo old, 50 to $60 \mathrm{~g}$ ) were used. A group of 5 carp was subjected to temperature stress by placing them into water of $12^{\circ} \mathrm{C}$ for $4 \mathrm{~h}$ every other day beginning $4 \mathrm{~d}$ prior to infection with $G$. carpelli. A second group of 5 carp remained untreated. All carp were infected with G. carpelli as described above, kept individually, and the excreted oocysts were collected and counted as previously described.

To study oocyst production and excretion in carp under immunosuppression, the fish were treated with hydrocortisole or were irradiated with X-rays as described above. In a first experiment, 18 carp 16 mo old, 40 to $50 \mathrm{~g}$ ) were used. The fish were divided into 3 groups of 6 . The first group was injected with hydrocortisole every 4 th day starting 4 d prior to exposure to the parasite. The second group was sham treated with PBS and the 3rd group received no injection. All fish were exposed to Goussia carpelli oocysts as described above, kept individually, and the excreted oocysts were collected and counted.

In a second experiment, 15 carp ( 6 mo old, 30 to $40 \mathrm{~g}$ ) were divided into 3 groups of 5 . The fish from Groups 1 and 2 were irradiated with X-rays as described above and then exposed to Goussia carpelli oocysts. In Group 1 , oocysts were given concurrently with the irradiation. In Group 2, the X-rays were applied $4 \mathrm{~d}$ prior to the oocyst exposure. The fish in Group 3 received no irradiation. All fish were exposed to $G$. carpelli oocysts, kept individually and the excreted oocysts collected and counted

Reinfection experiments. To examine the effect of immunosuppressants on the susceptibility of carp for a secondary infection with Goussia carpelli, fish which had recovered from a primary infection were treated with hydrocortisole, dexamethasone, or X-rays and then exposed to $G$. carpelli oocysts again. Three experiments were then performed. 
In the first experiment, 15 carp which had recovered from a primary infection and 15 naive carp were used. From each group, 5 carp were treated with hydrocortisole, dexamethasone, or Xrays and kept in tanks with Goussia carpelli oocysts for $10 \mathrm{~d}$. The intestines of the carp were then examined for $G$. carpelli stages (see Table 1).

In the second experiment, 15 carp that had recovered from a previous Goussia carpelli infection and 10 naive carp were used. Prior to a second exposure to $G$. carpelli oocysts, 5 previously exposed carp were irradiated with $X$ rays and 5 carp remained untreated. Additionally, 5 previously exposed carp were irradiated and then not re-exposed to G. carpelli oocysts. For controls, 10 naive carp were placed into the same tank with the immune fish. The intestines of all carp were examined for the presence of $G$. carpelli sporgonic stages at $10 \mathrm{dPE}$ (see Table 2).

In the third experiment, 25 carp which had recovered from a primary infection were used. Before inducing a primary infection in these carp, 15 were injected with hydrocortisole and 10 remained untreated. Prior to the induction of a secondary infection, 5 steroid-treated and 5 untreated carp were injected with hydrocortisole and 5 carp from each group were exposed to the parasite for the second time without hydrocortisole treatment. Additionally, 5 carp were injected with hydrocortisole and not exposed to the parasites again. From all carp, gut samples were taken at $10 \mathrm{~d} \mathrm{PE}$ and monitored for $G$. carpelli sporogonic stages (see Table 3).

In all experiments, carp were exposed to a secondary infection 2 mo after recovering from a primary infection.

Statistics. The number of oocysts produced by the different treatment groups was analysed for significant differences by nonparametric statistics (Mann-Whitney $U$-test). Observed differences were considered to be significant at $\mathrm{p}<0.05$.

\section{RESULTS}

\section{Oocyst production in immunosuppressed carp}

In these experiments, all carp which were exposed to Goussia carpelli oocysts acquired a coccidia infection and excreted oocysts. In the sediments of tanks at $20^{\circ} \mathrm{C}$, oocysts were first seen $10 \mathrm{~d} \mathrm{PE}$. In all groups, the carp excreted more the $50 \%$ of the oocysts between 10 and $15 \mathrm{dPE}$ (Fig. 1)

Carp affected by temperature stress excreted $240 \pm$ 25 oocysts, significantly more than untreated fish $(80 \pm$ 15 oocysts, $p<0.01$ ). The injection of PBS or hydrocortisole also induced a significant increase in the number of excreated oocysts (Fig. 1). In this experiment untreated control carp excreted (on average) 216 oocysts, PBS injected carp 3300 ( $p<0.001)$, and cortisol treated more than 11000 oocysts ( $p<0.0001$, Fig. 1). At Day 29 PE there were no oocysts found in the sediments from tanks with untreated or with PBS treated carp. Cortisole injected carp, however, continued to excrete oocysts

Carp irradiated with X-rays excreted more oocysts than untreated controls. Fish which were irradiated $4 \mathrm{~d}$ prior to oocyst exposure produced significantly more oocysts $(p<0.001)$ than carp which were given oocysts concurrently to the irradiation (Fig. 2).

\section{Reinfection experiments}

The results of the reinfection experiments are presented in Tables 1 to 3 . After recovering from a primary infection with Goussia carpelli, carp were refractory to a secondary infection. This was not affected by the administration of cortisol or irradiation. No G. carpelli 


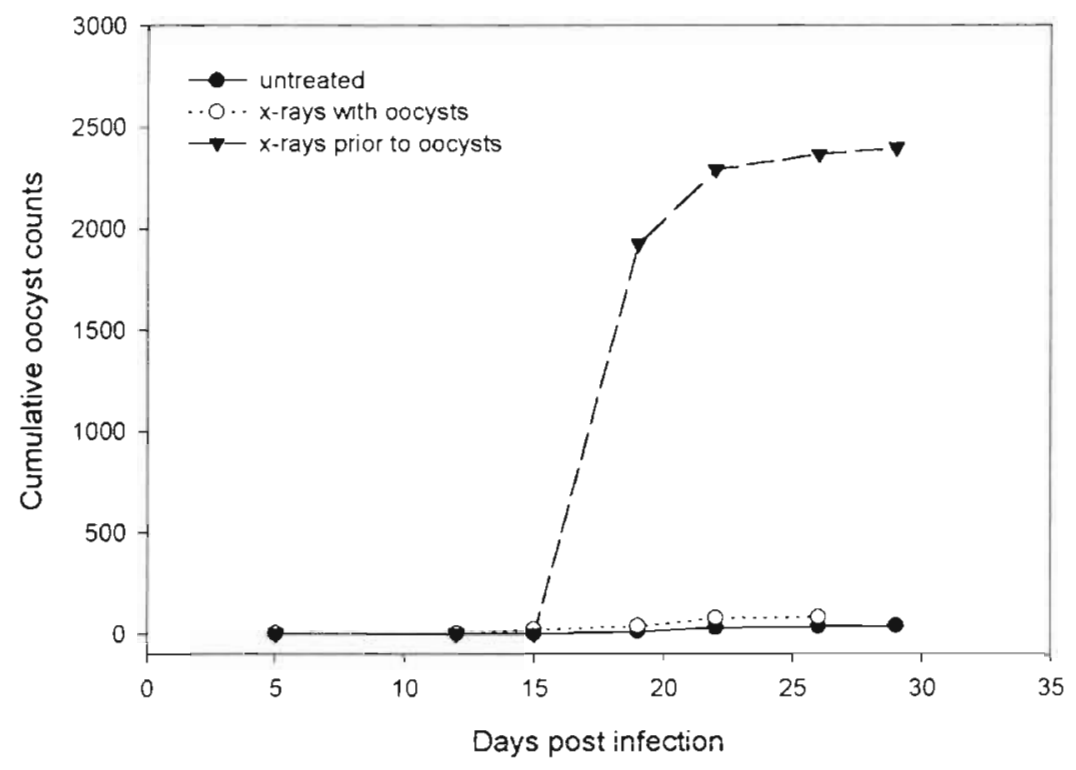

Fig. 2. Goussia carpelli infection in irradiated common carp. Cumulative mean oocyst counts from 5 individual carp from each treatment group. Untreated: oocyst counts from laboratory infected carp; X-rays with oocysts: carp were irradiated with X-rays at a dosage of 10 to 12 Gray and exposed to G. carpelli oocysts on the same day; X-rays prior to oocysts: carp were irradiated with $\mathrm{X}$ rays $4 \mathrm{~d}$ prior to oocyst exposure. Differences between untreated or X-ray with oocysts and $\mathrm{X}$-rays prior to oocysts were significant

stages were found in intestinal samples from carp which had been re-exposed. Additionally, the administration of hydrocortisole or irradiation did not induce a relapse of the infection. A secondary infection also failed in those carp that were immunosuppressed by cortisol injection during the primary infection (Table 3 ).

Throughout the study, any infections other than Goussia carpelli were not noticed to proliferate in immunocompromised carp.

Table 1. Effect of hydrocortisole, dexamethasone, and X-ray irradiation on the susceptibility of carp to secondary infections with Goussia carpelli. Immune: carp had recovered from a previous $G$. carpelli infection 2 mo earlier; naive: uninfected carp were exposed to a primary infection as controls. Hydrocortisole: $200 \mathrm{\mu g} \mathrm{g}^{-1}$ body weight hydrocortisone-21-hemisuccinate injected every $4 \mathrm{~d}_{\text {i }}$ dexamethasone: $2.5 \mathrm{\mu g} \mathrm{g}^{-1}$ body weight dexamethasone-21-isonicotinate injected into the body cavity of carp; X-rays: irradiation with X-rays at a dosage of between 10 and 12 Gray

$\left[\begin{array}{lll}\text { Group } & \text { Treatment } & \text { Number of fish used/infected } \\ \hline \text { Immune } & \text { Hydrocortisole } & 5 / 0 \\ & \text { Dexamethasone } & 5 / 0 \\ & \text { X-rays } & 5 / 0 \\ \text { Naive } & \text { Hydrocortisole } & 5 / 5 \\ & \text { Dexamethasone } & 5 / 5 \\ & \text { X-rays } & 5 / 5 \\ \hline\end{array}\right.$

\section{DISCUSSION}

Temperature stress, handling due to injecting a substance, and administration of exogenous corticosteroids clearly enhanced infection and oocyst production in carp exposed to the enteric coccidian parasite Goussia carpelli. This coincides with observations in hatchery populations, where juvenile carp and goldfish are affected by enteric coccidiosis when the fish were subjected to environmental stress like handling or change of food composition (Proske 1996).

In laboratory experiments, carp were very sensitive to handling and responded with elevated corticosteroid levels in blood plasma (Weyts 1997). Such enhanced cortisol concentrations are known to suppress immune functions, predispose animals to infectious diseases and worsen the course of such diseases in fish (Yin et al. 1995) and other vertebrates (Cohn 1991). In mammals, corticosteroids alter phagocyte functions like egress of inflammatory cells from blood vessels to a site of infection, phagocytosis, or interleukin production and influence lymphocyte blastogenesis mainly by acting on activated lymphocytes, which have increased numbers of steroid receptors (Cohn 1991). In fish, cortisol also has been observed to antagonise cell mediated immune responses. In vivo administered physiological concentrations of cortisol suppressed in vitro phagocytic responses of channel catfish granulocytes (Ainsworth et al. 1991). In Atlantic salmon, the number of surface-Ig-positive peripheral blood lymphocytes and the mitogenic response to LPS were downregulated upon cortisol injection (Esplid et al. 1996). In carp,

Table 2. Effect of X-ray irradiation on resistance of carp to secondary infections with Goussia carpelli. Immune: carp had recovered from a previous $G$. carpelli infection 2 mo earlier; naive: uninfected carp were subjected to a primary infection as controls. X-rays: irradiation with X-rays at a dosage between 10 and 12 Gray

\begin{tabular}{|llc|}
\hline \multirow{2}{*}{ Group } & Treatment & Number of fish used/infected \\
\hline Immune & No & $5 / 0$ \\
& X-rays & $5 / 0$ \\
\multirow{4}{*}{ Naive } & X-rays, no reinfection & $5 / 0$ \\
& No & $5 / 5$ \\
& X-rays & $5 / 5$ \\
\hline
\end{tabular}


Table 3. Effect of cortisol treatment of carp on the resistance to primary and secondary infection with Goussia carpelli. Secondary infection: carp were re-exposed to $G$. carpelli oocysts 2 mo after recovery from a primary infection. Cortisol: injection of $200 \mathrm{\mu g} \mathrm{g}^{-1}$ body weight hydrocortisone-21-hemisuccinate into the body cavity every 4 th day; control: naive carp were kept in the same tank with the immune fish to ensure the presence of infective oocysts

\begin{tabular}{|llc}
\hline $\begin{array}{l}\text { Treatment at } \\
\text { primary infection }\end{array}$ & $\begin{array}{l}\text { Treatment at } \\
\text { secondary infection }\end{array}$ & $\begin{array}{c}\text { Number of fish } \\
\text { used/infected }\end{array}$ \\
\hline No & No & $5 / 0$ \\
& Cortisol & $5 / 0$ \\
& Cortisol, no reinfection & $5 / 0$ \\
Cortisol & No & $5 / 0$ \\
& Cortisol & $5 / 0$ \\
Control & & $5 / 5$ \\
\end{tabular}

mitogen-activated lymphocytes responded with increased apoptosis upon cortisol treatment (Weyts 1997).

Defence mechanisms of carp against enteritic coccidiosis are not well understood (Davies \& Ball 1993). In Goussia carpelli-infected carp, macrophages and granulocytes infiltrated into infected tissue areas (Lom \& Dykova 1992, Jendrysek et al. 1994). These cells showed enhanced phagocytic activity in vivo (Jendrysek et al. 1994) and in vitro (Studnicka \& Siwicki 1990 Steinhagen \& Hespe 1997). A higher oocyst production in carp treated with cortisol as observed in the present study might be caused by an alteration of phagocyte migration and activity in these fish. Chickens treated with dexamethasone also produced higher numbers of oocysts following a primary and secondary infection with Eimeria mivati (Isobe \& Lillehoj 1993). In these animals, percentages of splenic cytotoxic-suppressor $T$ cell populations and mitogen-induced lymphoproliferation of these cells were significantly depressed. Thus, the enhanced disease susceptibility to coccidiosis was considered to reflect a drug-mediated immunosuppression (Isobe \& Lillehoj 1993). In a previous flow cytometric analysis of pronephros cells from $G$. carpelli-infected carp, we observed increased percentages of granulocytes but could not detect alterations in the composition of lymphocyte populations (Barckhausen \& Steinhagen unpubl.). The analysis of lymphocyte composition in carp, however, is hampered by the lack of suitable antibodies for labelling $T$ cell populations (Koumans-van Diepen 1993, Rombout et al. 1998). $T$ cell responses to coccidia infections in carp still need to be investigated.

In avian coccidiosis, the resistance to secondary infections could be eliminated by administration of agents that suppress cell-mediated immunity, such as cyclosporin $\mathrm{A}$, betamethasone and dexamethasone
(Lillehoj \& Trout 1994). A treatment with corticosteroids increased the susceptibility of chicken to secondary infections (Isobe \& Lillehoj 1993) or activated dormant stages from a prevoius Eimeria spp. infection (Zahner et al. 1994). In the present study, we investigated the susceptibility of carp to secondary infections of Goussia carpelli treated with corticosteroids and irradiation by $\mathrm{X}$-rays. The carp remained refractory to reinfections regardless of whether cortisol was given concurrently with the oocysts or in advance to secondary infection, and we did not observe a relapse of the infection due to possible previously unrecognized dormant stages. In addition, carp given a cortisol treatment during primary infection were not susceptible to reinfection. In contrast, secondary infections could be established in carp fed on tubificids which contained G. carpelli sporozoites and acted as paratenic host (Steinhagen \& Körting 1990). In hatcheries, carp from all age classes are found to be infected (Lom \& Dykova 1992). Tubificids collected from carp ponds induced $G$. carpelli infections when fed to parasite free carp. In nature, tubificids are major food organisms of 2 nd and 3rd yr carp and thus may represent a significant source of infection for these fish. Mechanisms which are involved in resistance of carp to secondary $G$. carpelli infections via the fecal contamination route remain to be investigated.

Acknowledgements. This study was financially supported by the Niedersächsische Minister für Wissenschaft und Kultur Mr S. H. Leenstra and Dr G. Wiegertjes, Wageningen, The Netherlands, kindly provided fertilized carp eggs. Many thanks to Dr Rittmann, Medical School, Hannover, for irradiating the carp, and to S. Bunnajirakul and K. Böttcher for counting oocysts.

\section{LITERATURE CITED}

Ainsworth AJ, Dexiang C, Waterstrat PR (1991) Changes in peripheral blood leukocyte percentages and function of neutrophils in stressed channel catfish. J Aquat Anim Health 3:41-47

Balm PH, Pottinger TG (1995) Corticotrope and melanotrope POMC-derived peptides in relation to interrenal function during stress in rainbow trout (Oncorhynchus mykiss) Gen Comp Endocrinol 98:279-288

Bly J, Quiniou SMA, Clem LW (1997) Environmental effects on fish immune mechanisms. In: Gudding R, Lillehaug $A$, Midtlyng PJ, Brown $F$ (eds) Fish vaccinology. Dev Biol Stand, Vol 90. Karger, Basel, p 33-43

Cohn LA (1991) The influence of corticosteriods on host defence mechanisms. J Vet Intern Med 5:95-104

Davies AJ, Ball SJ (1993) The biology of fish coccidia. Adv Parasitol 32:293-366

Elsaesser CF, Clem LW (1987) Cortisol-induced hematologic and immunologic changes in channel catfish (Ictalurus punctatus). Comp Biochem Physiol 87 A:405-408

Esplid S, Lokken GB, Steiro K, Bogwald J (1996) Effects of cortisol and stress on the immune system in Atlantic salmon (Salmo salar L.). Fish Shellfish Immunol 6:95-110 
Houghton G, Matthews RA (1990) Immunosuppression in juvenile carp. Cyprinus carpio $\mathrm{L}$ : the effects of the corticosteroids triamcinolone acetonide and hydrocortisone 21-hemisuccinate (cortisol) on acquired immunity and the humoral antibody response to Ichthyophthirius multifilis Fouquet. J Fish Dis 13:269-280

lsobe T, Lillehoj HS (1993) Dexamethasone suppresses T cellmediated immunity and enhances disease susceptibility to Eimeria mivati infection. Vet Immunol Immunopathol 39: $431-446$

Jendrysek S, Steinhagen D, Drommer W, Körting W (1994) Carp coccidiosis: intestinal histo- and cytopathology under Goussia carpelli infection. Dis Aquat Org 20:171-182

Kocylowski B, Zelazny J, Antychowitz J, Pancyk J (1976) Incidence of carp coccidiosis and its control. Bull Vet Inst Pulawy 20:12-17

Koumans-van. Diepen JCE (1993) Characterization of fish leukocytes. PhD thesis, Wageningen Agricultural University

Lillehoj HS, Trout JM (1994) CD8 + T cell-coccidia interactions. Parasitol Today 10:10-13

Lom J, Dykova I (1992) Protozoan parasites of fishes. Developments in aquaculture and fisheries sciences, Vol 26. Elsevier, Amsterdam

Maule AG, Tripp RA, Kaattari SL, Schreck CB (1989) Stress alters immune function and disease resistance in chinook salmon (Oncorhynchus tschawytscha). J Endocrinol 120: $135-142$

Proske C (1996) Probleme und Bedarf an Veterinärunterstützung bei der Aufzucht von Gartenteichfischen. In: Hofmann RW, Bernoth EM (eds) Tagung der Fachgruppe Fischkrankheiten der DVG, Königswartha, September 24-26, 1996. Deutsche Veterinärmedizinische Gesellschaft, Giessen, p 201-210

Rombout JHWM, Joosten PHM, Engelsma MY, Vos AP, Taverne $\mathrm{N}$, Taverne-Thiele JJ (1998) Indications for a distinct putative $T$ cell population in mucosal tissue of carp (Cyprinus carpio L.). Dev Comp Immunol 22:63-77

Editorial responsibility: Otto Kinne, Oldendorf/Luhe, Germany
Romeis B (1968) Mikroskopische Technik, 16th edn. Oldenbourg Publ, Munich

Schäperclaus W (1979) Fischkrankheiten, 4th edn. Akademie Verlag, Berlin

Sniesko JR (1974) The effects of environmental stress on outbreaks of infectious diseases of fishes. J Fish Biol 6: $197-208$

Steinhagen D. Hespe K (1997) Carp coccidiosis: activity of phagocytic cells from common carp infected with Goussia carpelli. Dis Aquat Org 31:155-159

Steinhagen D, Hespe K (1998) Carp coccidiosis: longevity and transmission of Goussia carpelli (Apicomplexa: Coccidia) in the pond environment. Folia Parasitol (in press)

Steinhagen D, Körting W (1990) The role of tubificid oligochaetes in the transmission of Goussia carpelli. J Parasitol $76: 104-107$

Steinhagen D, Körting W, van Muiswinkel WB (1989) Morphology and biology of Goussia carpelli (Protozoa: Apicomplexaj from experimentally infected common carp Cyprinus carpio. Dis Aquat Org 6:93-98

Steinhagen D, Oesterreich B, Körting W (1997) Carp coccidiosis: clinical signs and hematological observations of carp infected with Goussia carpellh. Dis Aquat Org 30 $137-143$

Studnicka M, Siwicki A (1990) The nonspecific immunological response in carp (Cyprinus carpio L.) during natural infection with Eimeria subepithelialis. Bamidgeh 42:18-21

Weyts FAA (1997) Corticosteroids and interleukin-1, messengers for communication between the endocrine and immune system in carp. PhD thesis, Wageningen Agricultural University

Yin Z, Lam TJ, Sin YM (1995) The effects of crowding stress on the non-specific immune response in fancy carp (Cyprinus carpio L.). Fish Shellfish Immunol 5:519-529

Zahner H, Homringhausen-Riester C, Bürger HJ (1994) Eimeriosen. In: Röllinghoff $\mathrm{M}$, Rommel $M$ (eds) Immunologische und molekulare Parasitologie. Gustav Fischer Publ, Jena, p 67-82

Submitted: June 26, 1998; Accepted: September 16, 1998 Proofs received from author(s): November 11, 1998 